\title{
Avaliação clínico- epidemiológica prospectiva de candidatos a doadores de sangue anti-HCV reagentes
}

A hepatite por vírus $\mathrm{C}$ (HVC) é um grave problema de saúde pública em vários países. Recentemente, foi instituída pelo Ministério da Saúde, a triagem sorológica obrigatória dos doadores de sangue, pela pesquisa do anticorpo anti-HCV. Na Unicamp, os doadores de sangue que são anti-HCV reagentes são encaminhados para avaliação clínica especializada no Ambulatório do Grupo de Estudo das Hepatites Virais, da Disciplina de Doenças Transmissíveis do Departamento de Clínica Médica da FCMUnicamp. Neste estudo, investigou-se os aspectos clínicos, epidemiológicos, laboratoriais, ultrasonográficos e histopatológicos presentes nestes doadores. Assim, foram avaliados clinicamente, no período de 1992-97, 790 doadores de sangue com teste anti-HCV EIA-2 fortemente reagente (relação entre a densidade ótica da amostra/cut-off $>3$ ), que haviam sido bloqueados no banco de sangue. Eram negativos para doença de Chagas, sífilis, hepatite B (HBsAg) e AIDS. Amostras de sangue foram coletadas, quando da primeira consulta ambulatorial, para a realização de hemograma, exames bioquímicos e novos testes sorológicos para a HVC (antiHCV EIA-2) e hepatite por vírus B (HVB) (HBsAg, anti-HBcAg, anti-HBsAg). Em 226 doadores anti-HCV EIA-2 reagentes, realizouse o teste suplementar de immunoblot para a HVC (RIBA-2). Em 209 doadores, pesquisou-se a presença do RNA do VHC pelo teste do $\mathrm{PCR}$, através de exame automatizado (HCVAMPLICOR, ROCHE). A ultra-sonografia abdominal foi realizada em 366 doadores e a biópsia hepática em 269 concordantes. Destes, 257 apresentavam níveis de ALT elevados e 12 , com níveis normais de ALT, exibiam hepatomegalia ao exame físico. Notou-se que 96\% eram EIA-2 repetidamente reagentes, 94\% eram assintomáticos e que apenas $2 \%$ referiram icterícia pregressa. Em 47\% detectou-se, pelo menos, um fator de risco para a transmissão do VHC, sendo o uso de drogas E.V. o principal deles $(23 \%)$. Atransfusão de sangue foi o segundo fator

\section{Prospective clinical and epidemiological evaluation of anti-HCV reagent blood donors candidates}

\author{
Hepatitis $\mathrm{C}$ virus ( $\mathrm{HCV})$ is a serious public
} health problem in several countries. Recently the Ministry of Health has instituted a mandatory serological screening for blood donors with routine anti-HCV antibody investigation. Thus, the blood donors at Unicamp, who are found to be anti-HCV reagents are conducted to specialized clinical evaluation at the Ambulatório do Grupo de Estudo das Hepatites Virais da Disciplina de Doenças Transmissíveis do Departamento de Clínica Médica da Faculdade de Ciências Médicas da Unicamp. In this study were investigated the various clinical, epidemiological, laboratorial, ultrasonographic and histopathological aspects, present in these donors. Therefore, between 1992 and 1997, 790 blood donors with anti-HCV EIA-2 strongly reagent (relationship between the sample optical density/cut-off $>3$ ) who had been detected at the blood bank serological screening, were evaluated in ambulatory environment. They were all negative for Chagas disease, syphilis, hepatitis $\mathrm{B}(\mathrm{HBsAg})$ and AIDS. Blood samples were collected at the first ambulatorial evaluation, for hemogram, biochemical tests and new serological tests for HCV ( anti-HCV EIA-2) and hepatitis B virus (HBV) (HBsAg, anti-HBcAg, anti-HBsAg). In blood samples of 226 repeatedly reagent antiHCV EIA-2 blood donors, supplementary immunoblot test for HCV (RIBA-2) was used. In 209 donors, the presence of HCV-RNA was investigated by the PCR test, by automatized test (HCV-AMPLICOR, ROCHE). The abdominal ultrasonography was made in 366 donors. In 269 patients liver biopsy was performed for the histopathological study. Out of these, 257 presented high ALT levels and 12 had hepatomegaly detectable during the physical examination. The follow-up of blood donors have shown that $96 \%$ were repeatedly EIA-2 reagent, $94 \%$ were symptomless and denied any hepatitis history, with $2 \%$ mentioning previous icterus. In $47 \%$ of this population at least one risk factor has been detected for the HCV transmission,

Recebido para publicação em 19/1/99. 
na transmissão da HVC (17\%). Hepatomegalia foi encontrada em $54 \%$, sendo de grau leve ou moderado em $95 \%$. Nos doadores com hepatomegalia intensa, houve maior freqüência de viremia. Esplenomegalia e sinais de hipertensão portal foram raramente encontrados no exame físico, denotando o baixo grau de comprometimento hepático na HVC. Houve poucos doadores com hipoalbuminemia (6\%), tendo a hipergamaglobulinemia sido observada em porcentual considerável dos mesmos (40\%). Aultra-sonografia abdominal mostrou-se alterada em $65 \%$ dos indivíduos, sendo a esteatose a alteração mais freqüentemente observada (50\%). Os níveis de ALT mostraram-se aumentados na maioria dos doadores (75\%), havendo associação entre estes e maior positividade para os testes de RIBA-2 (95,6\%) e PCR (82\%). Em 83,5\% dos doadores submetidos à biópsia hepática, diagnosticou-se hepatite crônica, geralmente classificada como ativa (89\%) e de grau leve ou moderado na maioria dos casos $(99,5 \%)$. O histopatológico foi normal em $1,5 \%$ dos doadores avaliados. O teste de RIBA-2 e a pesquisa do RNA do VHC pelo PCR foram positivos em, respectivamente, 92 e $76 \%$ dos doadores antiHCV EIA-2 reagentes. A pesquisa do RNA do VHC foi positiva em $82 \%$ dos indivíduos RIBA-2 reagentes, em $37,5 \%$ dos doadores RIBA-2 indeterminados e em $9 \%$ dos RIBA-2 negativos. Hepatites crônicas foram observadas em $50 \%$ dos doadores RIBA-2 indeterminados. Cerca de $30 \%$ dos doadores anti-HCV EIA-2 reagentes apresentaram marcadores séricos de infecção pregressa pelo VHB (anti-HBc). Nos pacientes com hepatites crônicas notaram-se resultados semelhantes ao dos doadores anti-HCV EIA-2 fortemente reagentes. A doença, via de regra, foi assintomática (92\%) e com poucos doentes referindo icterícia pregressa (4\%). Hepatomegalia foi detectada em $56 \%$, com fígado discreta ou moderadamente aumentado na maioria dos casos (93\%). O pequeno percentual de doentes com hepatomegalia acentuada (7\%), esplenomegalia (8\%) e sinais clínicos de hipertensão portal ou insuficiência hepática (1\%) refletem o baixo grau de comprometimento hepático da HVC nesta faixa etárea. Por estes resultados, considera-se insatisfatória, inadequada e ineficiente a triagem médica comumente realizada nos candidatos a doadores de sangue no Brasil. Doentes, com evidentes alterações clínicas e de alto risco epidemiológico para a transmissão do VHC e de outros vírus, acabam sendo liberados nesta triagem. Na verdade, a avaliação sorológica, the use of intravenous drugs being the main one $(23 \%)$. Blood transfusion was the second factor for HCV transmission (17\%). Hepatomegaly was detected in $54 \%$ of the cases, usually mild to moderate degree $(95 \%)$. In donors with intense hepatomegaly there was a higher frequency of viremia. Splenomegaly and signs of portal hypertension have seldom been found in the physical examination, indicating a low degree of hepatic compromising in HCV. There were few donors with hipoalbuminemia (6\%), opposite to the hipergamaglobulinemia which was present in a significant percentage (40\%). Abdominal ultrasonography has shown alterations in $65 \%$ of the subjects, being the steatosis the most frequent alteration observed (50\%). The ALT serum levels were higher in most of the donors evaluated $(75 \%)$, with an association between the high ALT serum levels and the high positivity for the RIBA-2 test (95.6\%) and for investigation of HCV-RNAin the blood (82\%). In $83.5 \%$ of the donors submitted to the liver biopsy, the histopathological exam has shown the presence of chronic hepatitis, usually classified as active $(89 \%)$ with mild or moderate grade in most of the cases $(99.5 \%)$. The histopathological exam of the liver was normal in $1.5 \%$ of blood donors. The RIBA-2 test and the HCV-RNAinvestigation by PCR were positive in respectively 92 and $76 \%$ of the anti-HCV EIA-2 reagent donors. The HCV-RNA research was positive in $82 \%$ of the RIBA-2 positive subjects, in $37.5 \%$ of the indeterminate RIBA-2 donors and in $9 \%$ of the negative RIBA-2 donors. Chronic hepatitis has also been observed in $50 \%$ of the histopathological exams of the anti-HCV EIA-2 reagent donors which were indeterminate RIBA-2. About $30 \%$ of anti-HCV EIA-2 donors evaluated presented positive serum markers for previous infection by HBV. In the patients histologically diagnosed as chronic hepatitis carriers, there have been found alterations very similar to the ones observed among the population of strongly reagent anti-HCV EIA-2. Thus the disease, usually, was symptomless (92\%) and with few patients mentioning previous icterus (4\%). Hepatomegaly was observed in $56 \%$ of these patients, with a mild or moderate increase in the liver size in most of the cases (93\%). The small percentage of patients with intense hepatomegaly $(7 \%)$, with splenomegaly $(8 \%)$ and with clinical signs of portal hypertension or hepatic insufficiency (1\%), reflect the low degree of hepatic compromising present in them. According to the results observed in this study, 
isoladamente e com suas limitações técnicas, tem, na maioria das vezes, o papel decisivo de bloquear ou liberar o sangue doado. we consider the commonly performed medical screening of blood donor candidates in our means to be unsatisfactory, inadequate and inefficient. This causes sick subjects, with evident clinical alterations and high epidemiological risk for the transmission of HCV and of other blood-borne virus, to end up being released. Actually, the serologic screening, isolated and with its known technical limits, will, most of the times, play a decisive role to block or release the blood donated.

Fernando Lopes Gonçales Junior

Tese apresentada à Faculdade de Ciências Médicas

da Universidade Estadual de Campinas para

obtenção do Título de Livre-Docente.

Campinas, SP, Brasil, 1998 